\title{
Seasonal Dynamics of Heavy Metals in Commercially Important Marine Fish from the Bay of Bengal Coast of Bangladesh
}

\author{
Md. Sirajul Islam ${ }^{*}$, Md. Hasan Imran' ${ }^{1}$ Md. Humayun Kabir ${ }^{1}$, Md. Masud-Un-Noby ${ }^{1}$, \\ Md. Enamul Hoq ${ }^{2}$, Sunzida Haque Rimu', Md. Safiur Rahman ${ }^{3}$ \\ ${ }^{1}$ Department of Environmental Science and Resource Management, Mawlana Bhashani Science and \\ Technology University, Tangail-1902, Bangladesh \\ ${ }^{2}$ Bangladesh Fisheries Research Institute, Freshwater Station, Mymensingh-2201, Bangladesh \\ ${ }^{3}$ Institute of Nuclear Science \& Technology, Bangladesh Atomic Energy Commission, Dhaka-1000, Bangladesh \\ *Corresponding author (Email: islammstazu@yahoo.com)| ORCID:0000-0002-7560-9334
}

How to cite this paper: Islam, M.S., Kabir, M.H., Noby, M.M., Hoq, M.E., Rimu, S.H. and Rahman, M.S. (2020). Seasonal Dynamics of Heavy Metals in Commercially Important Marine Fish from the Bay of Bengal Coast of Bangladesh. Grassroots Journal of Natural Resources, 3(2): 1-15. Doi:

https://doi.org/10.33002/nr2581.6853.03021

Received: 10 April 2020

Reviewed: 13 May 2020

Provisionally Accepted: 15 May 2020

Revised: 21 May 2020

Finally Accepted: 25 May 2020

Published: 22 June 2020

Copyright (C) 2020 by author(s)

This work is licensed under the Creative Commons Attribution International License (CC BY 4.0).

http://creativecommons.org/licenses/by/4.0/

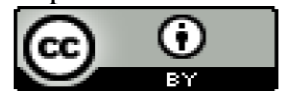

Open Access

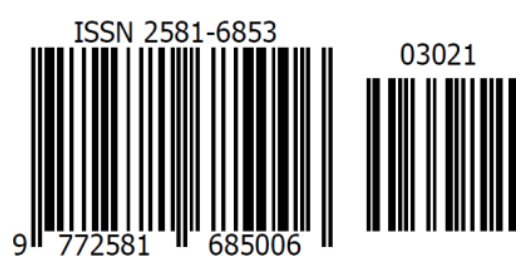

\begin{abstract}
This study was conducted to know the seasonal dynamics of heavy metal ( $\mathrm{Zn}, \mathrm{Cu}, \mathrm{Cr}, \mathrm{Cd}, \mathrm{Pb}$ and $\mathrm{Hg}$ ) concentrations in marine fish from the Bay of Bengal coast of Bangladesh in pre-monsoon, monsoon and postmonsoon seasons. The fish samples of various species viz. Churi (Trichiurus lepturus), Loittya (Harpadon nehereus), Ilish (Tenualosa ilisha) in St-1; Churi, Loittya, Ilish, Surma (Euthynnus affinis) in St-2; and Poa (Otolithoides pama), Loittya, Ilish in St-3 were collected seasonally from fish landing stations during December 2017 to November 2018. The samples were analyzed by using UNICAM-929 atomic absorption spectrophotometer following AOAC (2012) in the Food Laboratory of the SGS Bangladesh Limited., Dhaka. The results showed that among the metals, only $\mathrm{Zn}$ was detected in every station over the seasons. Overall metal accumulation, $\mathrm{Zn}$ content found more followed by $\mathrm{Cu}$ and $\mathrm{Cr}$, whereas $\mathrm{Cd}, \mathrm{Pb}$ and $\mathrm{Hg}$ were below the lower limit of detection in all the collected fish samples. Therefore, the study concluded that the fish are safe for human consumption as well as for public health and food safety measures ensured by common marine fish of Bangladesh.
\end{abstract}

\section{Keywords}

Heavy metals, Marine fish, Seasonal dynamics, Bay of Bengal coast, Bangladesh 
Doi: https://doi.org/10.33002/nr2581.6853.03021

\section{Introduction}

The concept of blue economy as well as marine fisheries resources in Bangladesh can be developed as emerging sectors. Blue economy started in the country after settlement of maritime boundary delimitation dispute with Myanmar and India, when Bangladesh allowed sovereign rights on all the living and mineral resources of the continental shelf extending up to 354 nautical miles (Jafrin, Saif and Hossain, 2016). There exist tremendous opportunities for Bangladesh to strengthen oceanbased economy as well as marine fisheries (Jafrin, Saif and Hossain, 2016; Moula, Parvin and Ferdaus, 2014). The Bay of Bengal is an inseparable part of Bangladesh and there is no doubt that the sea resources like exploration of fisheries resources for long-term food security, export earning, management of marine fisheries resources, protecting marine environment and biodiversity would determine future development and economic growth as well as food safety and security (Moula, Parvin and Ferdaus, 2014). The coastal pollution has been increasing significantly over the recent years with expanding environmental problems in many countries. Urban and industrial activities in coastal areas introduce significant amount of trace metals into the marine environment, causing permanent disturbances in marine ecosystems, leading to environmental and ecological degradation and constitute a potential risk to the floral and faunal species including human through food chains (Boran and Altinok, 2010). Studies show that metal pollution could be very high in the Indian subcontinent such as in Bangladesh since direct discharge of effluents almost always occurs, and from agricultural activities and as a consequence aquatic biota, and humans could be at a higher risks of exposure from toxic metals via the food chain pathways (BOBLME, 2015). Fish are widely consumed by coastal people in Bangladesh, since most harvested marine fish are located high in aquatic food chains, they accumulate metals from direct absorption from water and through tropic transfers, exposing human beings through food consumption.

The seafood is significant portion of a healthy diet due to high quality protein and other indispensable nutrients low in saturated fatty acids and may contain omega-3 fatty acids (Geetha et al., 2016). Seafood, especially finfish provides a major source of essential nutrients such as proteins, vitamins, fats and minerals which helps to maintenance the human life (Rao et al., 2016). Marine fish exposed to heavy metals consumed as sea food and there is a connecting pathway to transfer toxic metals in human beings and it often becomes mandatory to check chemical contaminants in foods from aquatic environment to understand their hazard levels. There are some studies on the contamination level of heavy metals in water and in sediments along the Karnafuli estuary and its adjacent coastal area. But no standardization and validation check of these data were done for national purpose. Information on the types of heavy metal in the Bay of Bengal coast including fish, coastal zones, rivers and other ecosystems is poorly documented. It is important to determine the concentrations of heavy metals in commercial fish and shrimps in order to evaluate the possible risk of human consumption. Further, their hazardous levels were compared with available certified safety guidelines proposed by FAO/WHO (1989) for human consumption. Therefore, various studies have been carried out worldwide on the metal contamination in different edible fish species but spatial variations of heavy metal bioaccumulation patterns in the pelagic and demersal fish from the continental shelf waters of Bangladesh have not been investigated.

The heavy metals are a group of pollutants which cause environmental degradation in coastal areas through the aquatic ecosystems in several ways (Raposo et al., 2009). Heavy metal is chosen as pollutant because they are widespread environmental contaminants, from either natural or anthropogenic sources, and are believed to be a threat to the health and survival of many marine or 
aquatic animals, including crustaceans (Lorenzon et al., 2001). Pollution of heavy metal has become a crucial concern due to ever-increasing contamination of water, soil and food in many regions of the world (Tang et al., 2013; Sow, Ismail and Zulkifli, 2013; Rahman, Saha and Molla, 2014). Therefore, investigation on heavy metal pollution in fish is important for characterizing health risks (Asuquo et al., 2004). Several studies showed that urban and industrial development contributes to metal contamination in aquatic environments (Xia et al., 2011; Tao et al., 2012). Heavy metals such as copper, iron, chromium and nickel are essential since they play an important role in the biological systems, whereas cadmium and lead are non-essential metals, as they are toxic, even in trace amounts (Fernandes et al., 2008). For the normal metabolism of the fish, the essential metals must be taken up from water, food or sediment (Canli and Atli, 2003). These essential metals can also produce toxic effects when the metal intake is excessively elevated (Tuzen, 2003). Lead a ubiquitous pollutant finds its way into the sea through industrial wastewater discharged by printing, dyeing and oil refineries industries (Komarnicki, 2005). The contaminated fish and crustaceans from aquatic environment may become a public health concern which is important to know the level of heavy metals in fish and shrimps for risk of human consumption (Cid et al., 2001). The use of fin and shellfish as bio-indicators of metal pollution in aquatic environments and suitability for human use from toxicological point were documented (Amin, Begum and Mondal, 2011). The objectives of the research were: (i) to investigate the seasonal variation of heavy metal concentration $(\mathrm{Zn}, \mathrm{Cu}, \mathrm{Cr}, \mathrm{Cd}, \mathrm{Pb}$ and $\mathrm{Hg})$ in different marine fish species in three seasons (pre-monsoon, monsoon and post-monsoon) collected from Chattogram, Cox's Bazar and Barguna coastal region; and (ii) to compare the results with the available national and international standard and previous studies.

\section{Materials and Methods}

Study area: The study was conducted in three coastal districts of Bangladesh during December 2017 to November 2018 (Figure 1). The fish samples were collected from three different sampling stations viz. Banshkhali Fish Landing Station, Chattogram: St-1; Sadar Fish Landing Station, Cox's Bazar: St-2; and Pathorghata Fish Landing Station, Barguna: St-3. These are the largest fish landing station in Bangladesh. Marine fish were brought to the landing stations from different fishing zone of the Bay of Bengal. Fishermen go to deep sea where valuable fish are available and when the Bay of Bengal is calm and quiet. They caught and stored fish in their trawlers with ice and back to the landing stations after 15 to 20 days for sale. The geographical location of these stations are: St1 at $22^{\circ} 19^{\prime} 39.43^{\prime \prime} \mathrm{N}$ latitude and $91^{\circ} 50^{\prime} 49.49^{\prime \prime} \mathrm{E}$ longitude; St-2 at $21^{\circ} 26^{\prime} 16.4^{\prime \prime} \mathrm{N}$ latitude and $92^{\circ} 01^{\prime} 47.7^{\prime \prime} \mathrm{E}$ longitude; and St-3 at $22^{\circ} 03^{\prime} 4.65^{\prime \prime} \mathrm{N}$ latitude and $89^{\circ} 58^{\prime} 24.13^{\prime \prime} \mathrm{E}$ longitude (Figure 1).

Table 1: Fish species collected from the Bay of Bengal coast of Bangladesh

\begin{tabular}{|c|c|c|c|}
\hline Fish & Chattogram (St-1) & Cox's Bazar (St-2) & Barguna (St-3) \\
\hline Demersal & $\begin{array}{l}\text { Churi (Trichiurus lepturus) } \\
\text { Loittya (Harpadon } \\
\text { nehereus) }\end{array}$ & $\begin{array}{l}\text { Churi (T. lepturus) } \\
\text { Loittya (H. nehereus) }\end{array}$ & $\begin{array}{l}\text { Poa (Otolithoides } \\
\text { pama) } \\
\text { Loittya (H. nehereus) }\end{array}$ \\
\hline Pelagic & Ilish (Tenualosa ilisha) & $\begin{array}{l}\text { Ilish (T. ilisha) } \\
\text { Surma (Euthynnus } \\
\text { affinis) }\end{array}$ & Ilish (T. ilisha) \\
\hline
\end{tabular}

Note: $\mathrm{St}=$ Station 
Sample collection: The common five marine fish species were collected during pre-monsoon (February to May), monsoon (June to September) and post-monsoon (October to January) seasons, respectively to investigate six heavy metals $(\mathrm{Zn}, \mathrm{Cu}, \mathrm{Cr}, \mathrm{Cd}, \mathrm{Pb}$ and $\mathrm{Hg}$ ) dynamics. The fish samples were as Churi (Trichiurus lepturus), Loittya (Harpadon nehereus) and Ilish (Tenualosa ilisha) from St-1; Churi, Loittya, Ilish and Surma (Euthynnus affinis) from St-2; and Poa (Otolithoides pama), Loittya and Ilish from St-3 (Table 1). Five fish of each species were collected from fish landing stations in the morning from Chattogram, Cox's Bazar and Pathorghata (Barguna). The average weight of each fish sample was $200 \mathrm{~g}$. The samples were then brought to the laboratory with ice box, kept at deep freezer for preservation and to avoid further contamination until analysis. The marine fish samples are divided into two categories such as demersal and pelagic (Table 1). Demersal fish are found in the seafloor consisting of mud, sand, gravel or rocks on the continental shelf, outer continental margin on the continental slope and the continental rise. Pelagic fish live in the pelagic zone of ocean surface neither close to the bottom nor near the shore in contrast with demersal fish that do live on or near the bottom. As a result, pelagic fish must search larger volumes than demersal fish (Lal and Fortune, 2000).

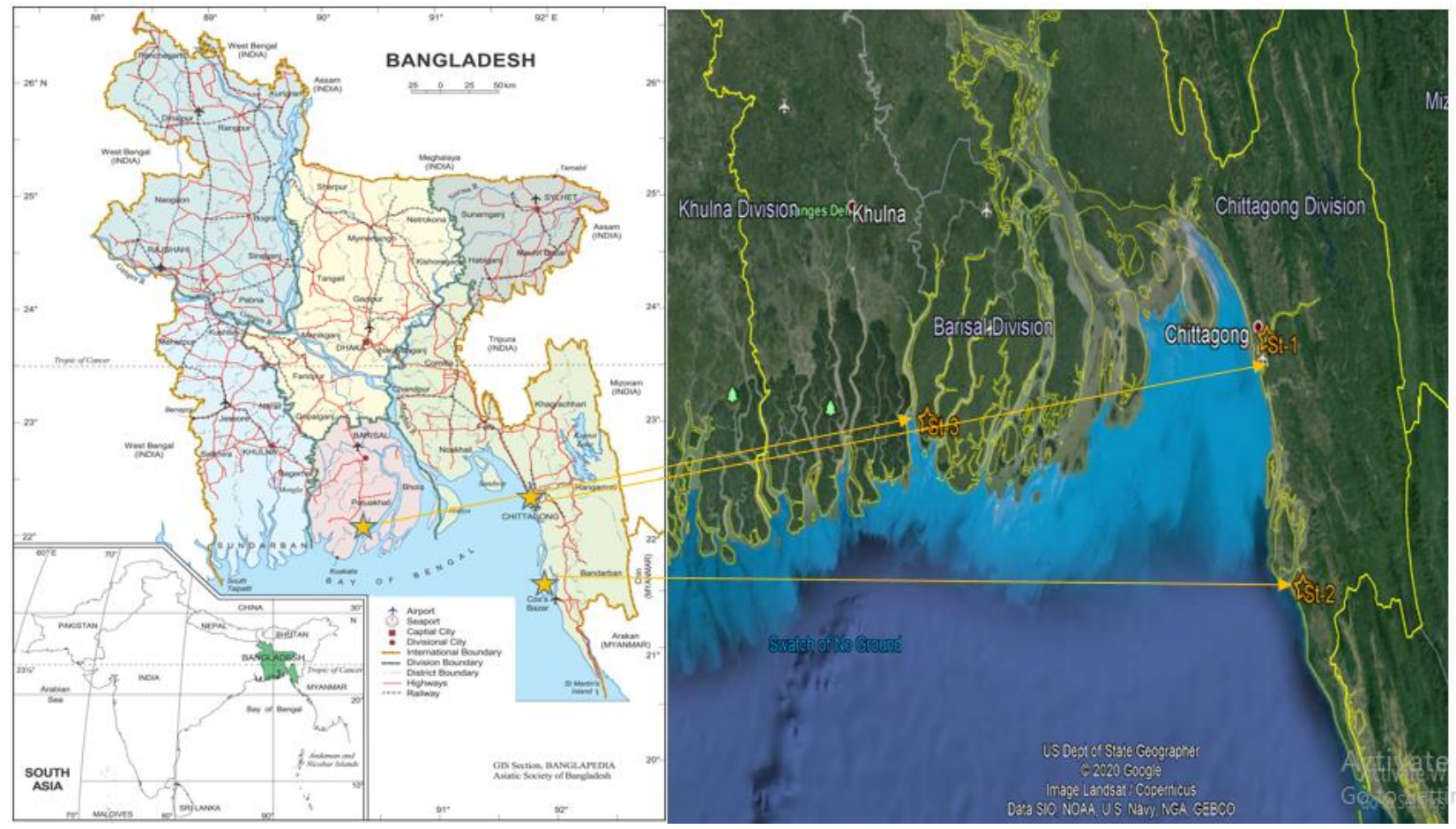

Figure 1: Map showing the study areas in Chattogram, Cox's Bazar and Pathorghata (Barguna) coastal region of Bangladesh

Sample pre-treatment: The collected fish samples thoroughly washed with Milli-Q water after removing the scales, and muscle portion, which took for further processing. Muscle tissue was dried at $110^{\circ} \mathrm{C}$, powdered with pestle and mortar and stored until chemical analysis. Heavy metals ( $\mathrm{Zn}, \mathrm{Cu}, \mathrm{Cr}, \mathrm{Cd}, \mathrm{Pb}$ and $\mathrm{Hg}$ ) were analyzed after digesting the homogenized samples in a mixture of nitric and per-chloric acid (Kumar, Karthik and Rao, 2010). Digestion were carried out after 0.5 gm homogenized powdered sample was placed in a Teflon beaker and digested with few drops of sodium chloride solution (30\%) and a $10 \mathrm{ml}$ mixture (1:5) of concentrate nitric acid (65\%) and concentrated per-chloric acid (70\%). The free chlorine developed loosens the chemical bonds in 
organic compounds after gentle heating $\left(70 \pm 5^{\circ} \mathrm{C}\right)$ in a water bath for $12 \mathrm{hrs}$ and destroys the organic matter in order to transfer the metals into the solution. The digested samples were centrifuged and the supernatant analyzed.

Sample analysis: To know the level of metal ( $\mathrm{Zn}, \mathrm{Cu}, \mathrm{Cr}, \mathrm{Cd}, \mathrm{Pb}$ and $\mathrm{Hg}$ ) concentrations, samples were analyzed by using UNICAM-929 atomic absorption spectrophotometer (AAS) following AOAC (2012) 19th edition by ICP-OES in the Food Laboratory of the SGS Bangladesh Limited, Dhaka, Bangladesh. Before analysis, a bit of muscle, the whole liver and two gill arches from each fish were removed. Samples of tissues from each fish were weighed and dried. A microwave digestion system (CEM MDS-2000) was used to prepare the samples for analysis. The advantage of microwave digestion against the classical method are the shorter time, less consumption of acid and keeping volatile compounds in the solution (Krushevska, Barnes and Amarasiriwaradena, 1993; Gulmini, Ostacoli and Zelano, 1994). After digestion, the residues diluted to $25 \mathrm{ml}$ with $2.5 \%$ of $\mathrm{HNO}_{3}$. Instrument calibrated standard solutions were prepared from commercial materials. The water used was deionized and distilled.

Statistical analysis: The collected data were compiled and tabulated in proper form and were subjected to statistical analysis. The Microsoft Office Excel software was used to present and interpret the collected data. The results of the study were presented in graphs and tabular forms.

\section{Results and Discussion}

Average concentrations of $\mathrm{Zn}, \mathrm{Cu}$ and $\mathrm{Cr}$, recorded from the muscles of five marine fish species during pre-monsoon, monsoon, and post-monsoon are presented in Tables 2-4 and Figures 2-7. Other three heavy metals such as $\mathrm{Cd}, \mathrm{Pb}$, and $\mathrm{Hg}$ were not detected during the laboratory examination in all five fish species in all seasons.

\section{Seasonal variations of heavy metals in fish from Chattogram (St-1)}

Zinc ( $\mathrm{Zn}$ ): The zinc is found in all organisms as well as fish and it is an essential trace element for metabolic processes (Saha et al., 2016). Among the studied six heavy metals only $\mathrm{Zn}$ concentrations was found in fish of the Chattogram region. In Churi (T. lepturus), the $\mathrm{Zn}$ concentrations found $6.1,5.42$ and $6.04 \mathrm{mg} / \mathrm{kg}$ in pre-monsoon, monsoon and post-monsoon seasons, respectively (Table 2) which were within the acceptable limit. The highest Zn content (6.1 $\mathrm{mg} / \mathrm{kg})$ was found at pre-monsoon and lowest content $(5.42 \mathrm{mg} / \mathrm{kg})$ was at monsoon season. In Loittya (H. nehereus), the highest $\mathrm{Zn}$ content $(3.21 \mathrm{mg} / \mathrm{kg})$ was recorded at post-monsoon and the lowest $(2.81 \mathrm{mg} / \mathrm{kg})$ was at monsoon season. At the pre-monsoon, monsoon and post-monsoon season, the Zn concentrations were $3.12,2.81$ and $3.21 \mathrm{mg} / \mathrm{kg}$, respectively (Table 2), which were within the acceptable limit conferring to FAO/WHO (1989).

Table 2: Seasonal variation of heavy metal concentration in fish from Chattogram coast

\begin{tabular}{ccccc}
\hline Fish & $\begin{array}{c}\text { Heavy metals } \\
(\mathrm{mg} / \mathrm{kg})\end{array}$ & Pre-monsoon & Monsoon & Post-monsoon \\
\cline { 3 - 5 } & $\mathrm{Zn}$ & 6.10 & 5.42 & 6.04 \\
& $\mathrm{Cu}$ & $\mathrm{ND}$ & ND & ND \\
Churi (T. lepturus $)$ & $\mathrm{Cr}$ & $\mathrm{ND}$ & $\mathrm{ND}$ & ND
\end{tabular}




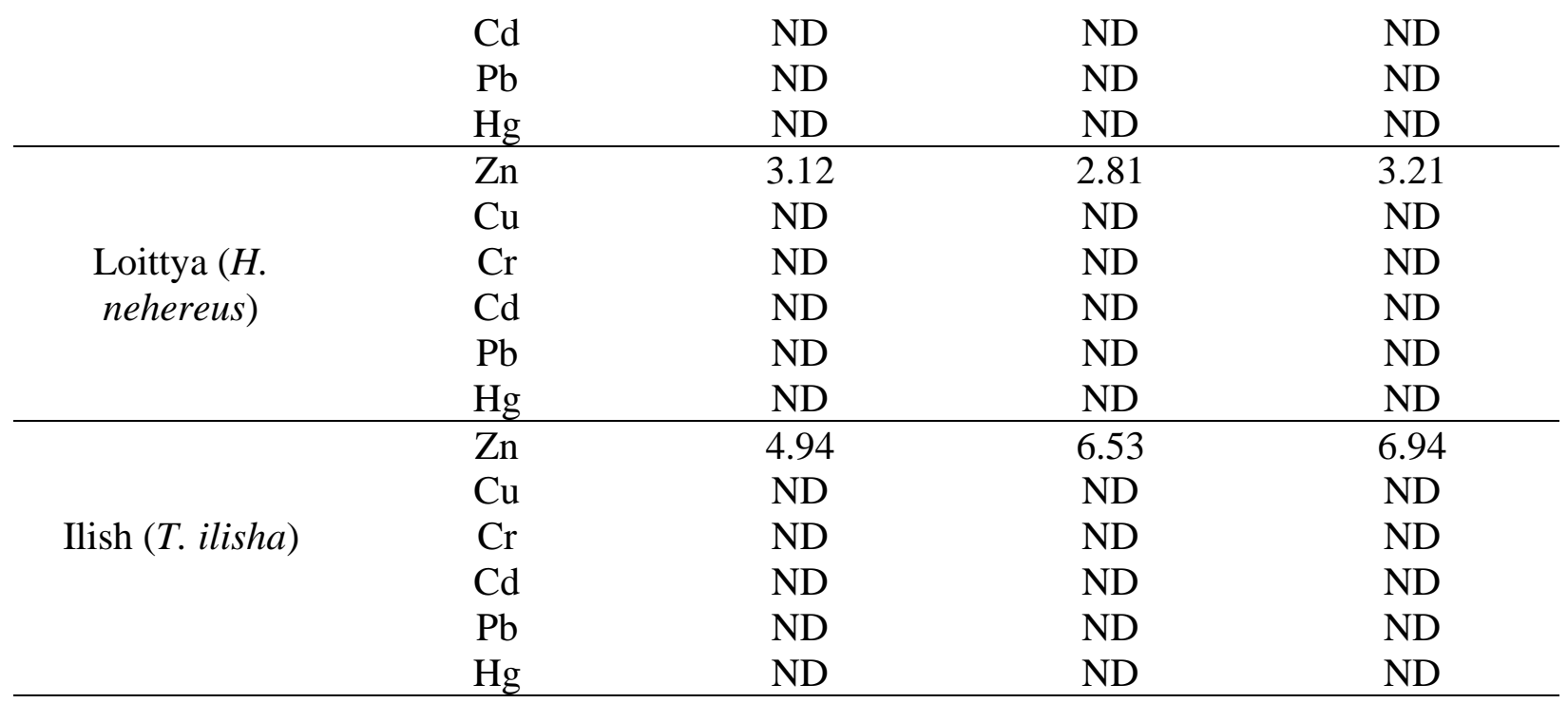

Note: ND = Not Detected (below lower limit of detection according to Shrivastava and Gupta, 2011).

During the study, Zn concentrations in Ilish (T. ilisha) were found 4.94, 6.53 and $6.94 \mathrm{mg} / \mathrm{kg}$ in pre-monsoon, monsoon and post-monsoon season, respectively (Table 2). The highest content $(6.94 \mathrm{mg} / \mathrm{kg})$ was at post-monsoon and lowest $(4.94 \mathrm{mg} / \mathrm{kg})$ was at pre-monsoon season. The $\mathrm{Zn}$ concentrations in Ilish fish were within the acceptable limit as per FAO/WHO (1989) recommendation. According to Bashir and Alhemmali (2015), the maximum Zn was found 55.8 $\mathrm{mg} / \mathrm{kg}$ (dry weight) whereas minimum was $17.7 \mathrm{mg} / \mathrm{kg}$ (dry weight) in fish which are much higher than the present findings. Among the heavy metals studied $\mathrm{Zn}, \mathrm{Cu}, \mathrm{Cr}, \mathrm{Cd}$ and $\mathrm{Pb}$ detected in fish and shrimp species were within acceptable limits (Islam et al., 2017). Zinc was found more in deep sea fish muscles in the Indian sub-continent (Rao and Sreedhar, 2017). The concentrations of Zn in different marine fish species were found within the range of variability reported for various fish species in different parts of Bangladesh (Saha et al., 2016). The Epinephelus sp. exhibited a tendency to accumulated high concentration of $\mathrm{Zn}$ when compared to other species (64.61 \pm 6.46 $\mathrm{mg} / \mathrm{g}$ ) found in the Red sea of Egypt (El-Moselhy et al., 2014), which are much higher than present study.

Copper $(\mathrm{Cu})$, Chromium $(\mathrm{Cr})$, Cadmium $(\mathrm{Cd})$, Lead $(\mathrm{Pb})$ and Mercury $(\mathrm{Hg})$ : These heavy metals were not detected in the five fish samples analyzed during the laboratory examination in all seasons (Table 2).

Seasonal variation of heavy metals in fish from Cox's Bazar (St-2)

Zinc (Zn): The concentrations of $\mathrm{Zn}$ in Churi fish were found 5.02, 4.02 and $6.23 \mathrm{mg} / \mathrm{kg}$ in premonsoon, monsoon and post-monsoon season, respectively (Table 3$)$. The highest $(6.23 \mathrm{mg} / \mathrm{kg}$ ) and lowest $(4.02 \mathrm{mg} / \mathrm{kg})$ contents were found at post-monsoon and monsoon season, respectively which within the acceptable limit of FAO/WHO (1989) standard. In Loittya fish, Zn concentration were recorded 2.83, 2.64 and $4.50 \mathrm{mg} / \mathrm{kg}$ in pre-monsoon, monsoon and post-monsoon season, respectively, whereas in Ilish it was $4.73,4.86$ and $11.10 \mathrm{mg} / \mathrm{kg}$ in pre-monsoon, monsoon and post-monsoon season, respectively (Table 3). In Loittya fish, highest and lowest $\mathrm{Zn}$ contents were 
4.50 and $2.64 \mathrm{mg} / \mathrm{kg}$ at post-monsoon and monsoon seasons, respectively, although in Ilish fish the highest and lowest were 11.10 and $4.73 \mathrm{mg} / \mathrm{kg}$ at post-monsoon and pre-monsoon season, respectively. During the study, $\mathrm{Zn}$ in Surma (E. affinis) fish was $4.02,7.71$ and $12.46 \mathrm{mg} / \mathrm{kg}$ in premonsoon, monsoon and post-monsoon seasons, respectively (Table 3). The highest content (12.46 $\mathrm{mg} / \mathrm{kg})$ was found at post-monsoon, while the lowest $(4.02 \mathrm{mg} / \mathrm{kg})$ was at pre-monsoon season and found within the acceptable limit. The study found that $\mathrm{Zn}$ concentration in Loittya and Hilsha fish were within the permissible limit. The maximum and minimum $\mathrm{Zn}$ concentration were 55.8 and $17.7 \mathrm{mg} / \mathrm{kg}$ (dry weight) in coastal fish of Malaysia (Bashir and Alhemmali, 2015), which are much higher than the present results.

Copper $(\mathrm{Cu})$ : The $\mathrm{Cu}$ is an essential element due to its presence in several enzymes and its necessity for hemoglobin synthesis (Sivaperumal et al., 2007). However, very high levels of Cu can cause acute toxicity (Saha et al., 2016). Different regulatory body established a safe limit for $\mathrm{Cu}$ concentration. The concentration of $\mathrm{Cu}$ was found in Churi, Loittya, Ilish and Surma fish were $0.66,1.01,1.38$ and $1.36 \mathrm{mg} / \mathrm{kg}$, respectively only in the post-monsoon season (Table 3). According to Najjar at el. (2016), the maximum $\mathrm{Cu}$ concentration was $81.58 \mathrm{mg} / \mathrm{kg}$ and the minimum was $6.61 \mathrm{mg} / \mathrm{kg}$ in fish which are much higher than the present investigation. However, heavy metals in fish at the pre-monsoon and monsoon seasons were not detected during laboratory examination. The $\mathrm{Cu}$ concentration was within the acceptable limit of FAO/WHO (1989) standard. The copper content of deep sea fish was found more in Neobyticus followed by $C$. investigates and Basogigus, whereas less amount was found in B. splendens (Rao and Sreedhar, 2017). Saha et al. (2016) recorded maximum concentrations of $\mathrm{Cu}(8.54 \mu \mathrm{g} / \mathrm{g})$ in I. megaloptera during summer which was lower than the recommended concentrations by various authorities and the variability of $\mathrm{Cu}$ concentrations was also like other published studies. The herbivore $S$. rivulatus accumulated the highest concentration of $\mathrm{Cu}(18.62 \pm 2.52 \mathrm{mg} / \mathrm{g}$; while another herbivore species (S. gibbus) showed the lowest values $(0.76 \pm 0.13 \mathrm{mg} / \mathrm{g})$ from Red sea fish in Egypt (El-Moselhy et al., 2014) and revealed that these concentration are much higher than present study.

$\mathrm{Cr}, \mathrm{Cd}, \mathrm{Pb}$ and $\mathrm{Hg}$ : These heavy metals were not detected in all fish samples analyzed during the study period in all the seasons (Table 3 ).

Table 3: Seasonal variation of heavy metal concentration in fish from Cox's Bazar coast

\begin{tabular}{ccccc}
\hline \multirow{2}{*}{ Fish } & $\begin{array}{c}\text { Heavy metals } \\
(\mathrm{mg} / \mathrm{kg})\end{array}$ & \multicolumn{3}{c}{ Seasons } \\
\cline { 3 - 5 } & $\mathrm{Zn}$ & Pre-monsoon & Monsoon & Post-monsoon \\
\hline \multirow{5}{*}{ Churi (T. lepturus) $)$} & $\mathrm{Cu}$ & $\mathrm{ND}$ & 4.02 & 6.23 \\
& $\mathrm{Cr}$ & $\mathrm{ND}$ & $\mathrm{ND}$ & 0.66 \\
& $\mathrm{Cd}$ & $\mathrm{ND}$ & $\mathrm{ND}$ & $\mathrm{ND}$ \\
& $\mathrm{Pb}$ & $\mathrm{ND}$ & $\mathrm{ND}$ & $\mathrm{ND}$ \\
& $\mathrm{Hg}$ & $\mathrm{ND}$ & $\mathrm{ND}$ & $\mathrm{ND}$ \\
& $\mathrm{Zn}$ & 2.83 & 2.64 & $\mathrm{ND}$ \\
\hline \multirow{5}{*}{ Loittya $(H}$. & $\mathrm{Cu}$ & $\mathrm{ND}$ & $\mathrm{ND}$ & 4.50 \\
nehereus $)$ & $\mathrm{Cr}$ & $\mathrm{ND}$ & $\mathrm{ND}$ & 1.01 \\
& $\mathrm{Cd}$ & $\mathrm{ND}$ & $\mathrm{ND}$ & $\mathrm{ND}$ \\
& $\mathrm{Pb}$ & $\mathrm{ND}$ & $\mathrm{ND}$ & $\mathrm{ND}$ \\
& $\mathrm{Hg}$ & $\mathrm{ND}$ & $\mathrm{ND}$ & $\mathrm{ND}$ \\
\hline
\end{tabular}


Doi: https://doi.org/10.33002/nr2581.6853.03021

\begin{tabular}{lllll}
\hline & $\mathrm{Zn}$ & 4.73 & 4.86 & 11.10 \\
\multirow{5}{*}{ Ilish (T. ilisha) } & $\mathrm{Cu}$ & $\mathrm{ND}$ & $\mathrm{ND}$ & 1.38 \\
& $\mathrm{Cr}$ & $\mathrm{ND}$ & $\mathrm{ND}$ & $\mathrm{ND}$ \\
& $\mathrm{Cd}$ & $\mathrm{ND}$ & $\mathrm{ND}$ & $\mathrm{ND}$ \\
& $\mathrm{Pb}$ & $\mathrm{ND}$ & $\mathrm{ND}$ & $\mathrm{ND}$ \\
& $\mathrm{Hg}$ & $\mathrm{ND}$ & $\mathrm{ND}$ & $\mathrm{ND}$ \\
\hline \multirow{5}{*}{ Surma (E. affinis) } & $\mathrm{Zn}$ & 4.02 & 7.71 & 12.46 \\
& $\mathrm{Cu}$ & $\mathrm{ND}$ & $\mathrm{ND}$ & 1.36 \\
& $\mathrm{Cr}$ & $\mathrm{ND}$ & $\mathrm{ND}$ & $\mathrm{ND}$ \\
& $\mathrm{Cd}$ & $\mathrm{ND}$ & $\mathrm{ND}$ & $\mathrm{ND}$ \\
& $\mathrm{Pb}$ & $\mathrm{ND}$ & $\mathrm{ND}$ & $\mathrm{ND}$ \\
& $\mathrm{Hg}$ & $\mathrm{ND}$ & $\mathrm{ND}$ & $\mathrm{ND}$ \\
\hline
\end{tabular}

Note: ND = Not Detected (below the lower limit of detection according to Shrivastava and Gupta, 2011).

Seasonal variation of heavy metals in fish from Pathorghata (St-3)

Zinc (Zn): During the study, Zn concentration in Poa (O. pama) was $6.61,3.74$ and $2.48 \mathrm{mg} / \mathrm{kg}$ in pre-monsoon, monsoon and post-monsoon season, respectively (Figure 2), whereas the highest and lowest contents were 6.61 and $2.48 \mathrm{mg} / \mathrm{kg}$ at pre-monsoon and post-monsoon seasons, respectively. In Loittya, $\mathrm{Zn}$ concentrations were 3.82, 2.81 and $6.24 \mathrm{mg} / \mathrm{kg}$ in pre-monsoon, monsoon and postmonsoon seasons, respectively (Figure 3 ), while the highest content $(6.24 \mathrm{mg} / \mathrm{kg}$ ) was at postmonsoon and the lowest content $(2.81 \mathrm{mg} / \mathrm{kg})$ was at monsoon season. In pre-monsoon, monsoon and post-monsoon seasons, $\mathrm{Zn}$ concentrations were $4.88,6.46$ and $3.05 \mathrm{mg} / \mathrm{kg}$, respectively in Ilish fish (Figure 4). The highest $\mathrm{Zn}$ content $6.46 \mathrm{mg} / \mathrm{kg}$ was at monsoon and lowest content $3.05 \mathrm{mg} / \mathrm{kg}$ was at post-monsoon season in Ilish. The results revealed that $\mathrm{Zn}$ concentration in studied fish were within the permissible limit set by FAO/WHO (1989). The highest and lowest $\mathrm{Zn}$ concentration was 55.8 and $17.7 \mathrm{mg} / \mathrm{kg}$ (dry weight) in coastal fish in Malaysia (Bashir and Alhemmali, 2015)

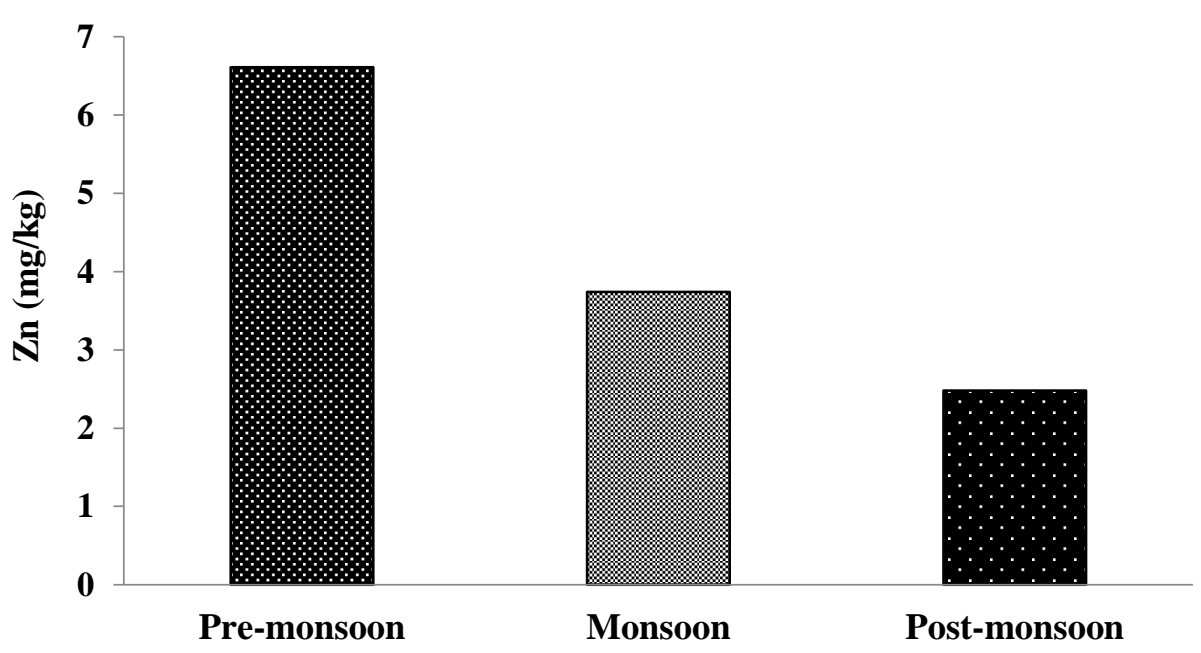

Season

Figure 2: Seasonal variation of $\mathrm{Zn}$ concentration in Poa (O. pama) from Pathorghata 
which are much higher than the present study. A previous study on Tigris river fish found that the highest concentration of $\mathrm{Zn}$ was $5.264 \mathrm{mg} / \mathrm{kg}$ in autumn while the lowest concentration of $\mathrm{Zn}$ was $0.13 \mathrm{mg} / \mathrm{kg}$ in winter and the results showed that the Zinc concentrations were higher than the acceptable limit according to FAO/ WHO standards (Hussen and Mohammed, 2019).

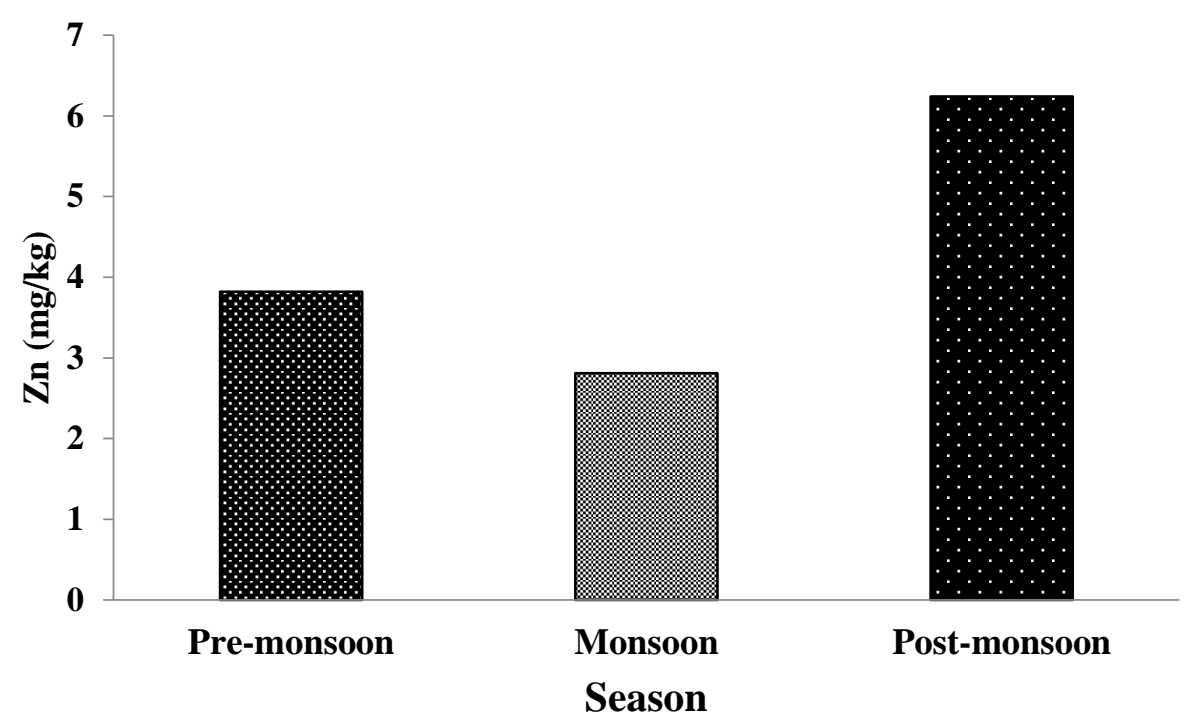

Figure 3: Seasonal variation of $\mathrm{Zn}$ concentration in Loittya (H. nehereus) from Pathorghata

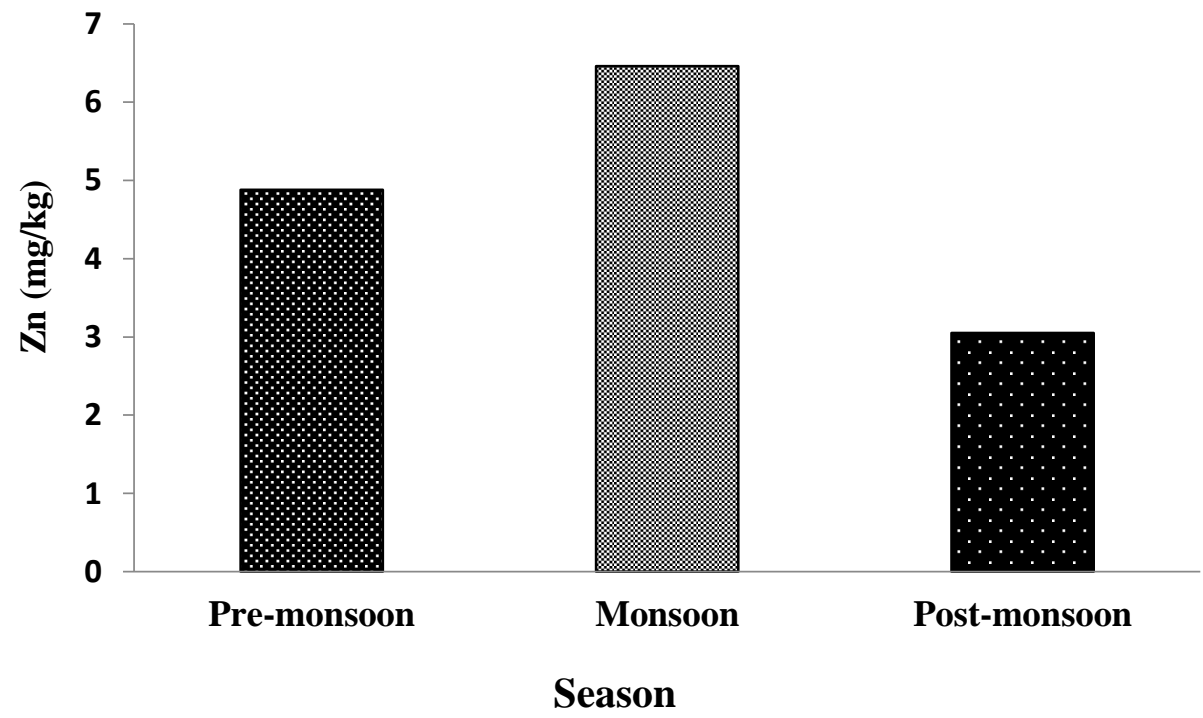

Figure 4: Seasonal variation of Zn concentration in Ilish (T. ilisha) from Pathorghata

Copper $(\mathrm{Cu})$ : During the study, $\mathrm{Cu}$ in Poa fish was $0.72,0.46$ and $2.48 \mathrm{mg} / \mathrm{kg}$ in pre-monsoon, monsoon and post-monsoon seasons, respectively (Figure 5). The highest $\mathrm{Cu}$ content was 2.48 $\mathrm{mg} / \mathrm{kg}$ at post-monsoon and lowest was $0.46 \mathrm{mg} / \mathrm{kg}$ at monsoon season. The $\mathrm{Cu}$ concentration were $1.08,1.20$ and $1.15 \mathrm{mg} / \mathrm{kg}$ in pre-monsoon, monsoon and post-monsoon seasons, respectively 
(Figure 6) in Loittya fish, whereas highest content $(1.20 \mathrm{mg} / \mathrm{kg})$ was found at monsoon and lowest $(1.08 \mathrm{mg} / \mathrm{kg})$ was at pre-monsoon season. In Ilish, the highest $\mathrm{Cu}$ content $(1.27 \mathrm{mg} / \mathrm{kg})$ was found at monsoon and lowest $(1.20 \mathrm{mg} / \mathrm{kg})$ was at post-monsoon season, with the mean $\mathrm{Cu}$ concentrations were $1.22,1.27$ and $1.20 \mathrm{mg} / \mathrm{kg}$ in pre-monsoon, monsoon and post-monsoon seasons, respectively (Figure 7). The $\mathrm{Cu}$ concentration in fish species were within the acceptable limit according to FAO/WHO (1989) standard. According to Najjar at el. (2016) the maximum Cu concentration was $81.58 \mathrm{mg} / \mathrm{kg}$ and the minimum was $6.61 \mathrm{mg} / \mathrm{kg}$ in fish which are much higher than the present study. The highest concentration of $\mathrm{Cu}$ was $6.05 \mathrm{mg} / \mathrm{kg}$ in autumn, while the lowest concentration of $\mathrm{Cu}$ was $0.02 \mathrm{mg} / \mathrm{kg}$ in and the results showed that the copper concentrations higher than the acceptable limit according to FAO/WHO standards (Hussen and Mohammed, 2019).

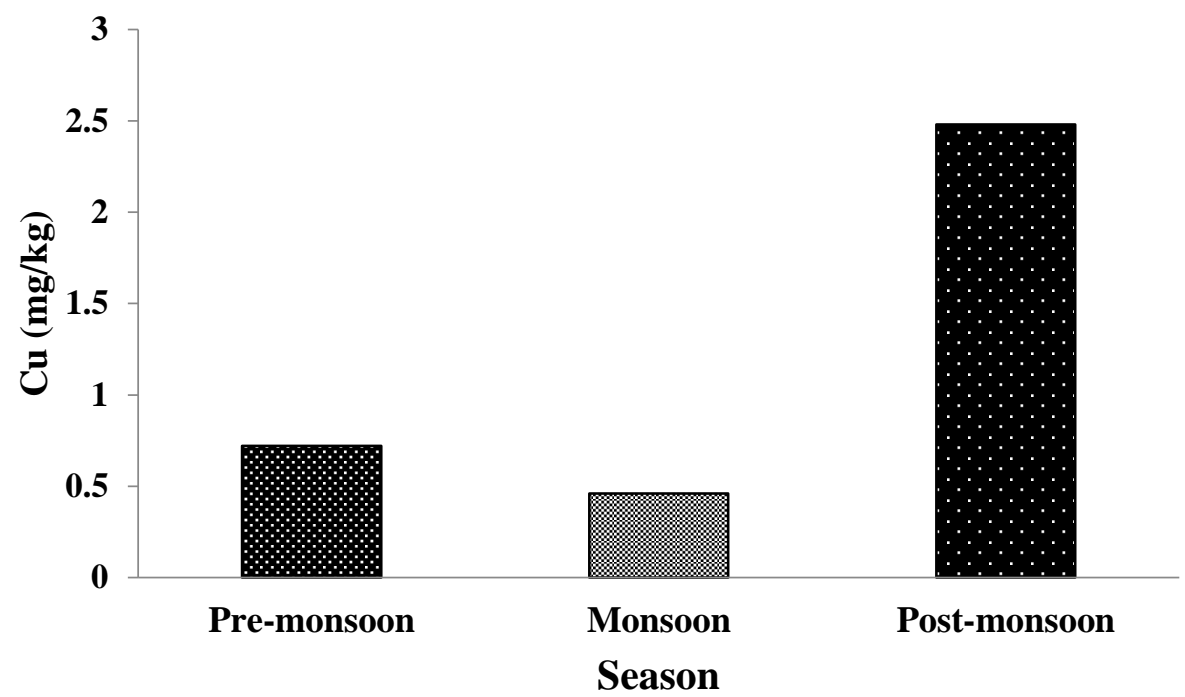

Figure 5: Seasonal variation of $\mathrm{Cu}$ concentration in Poa (O. pama) from Pathorghata

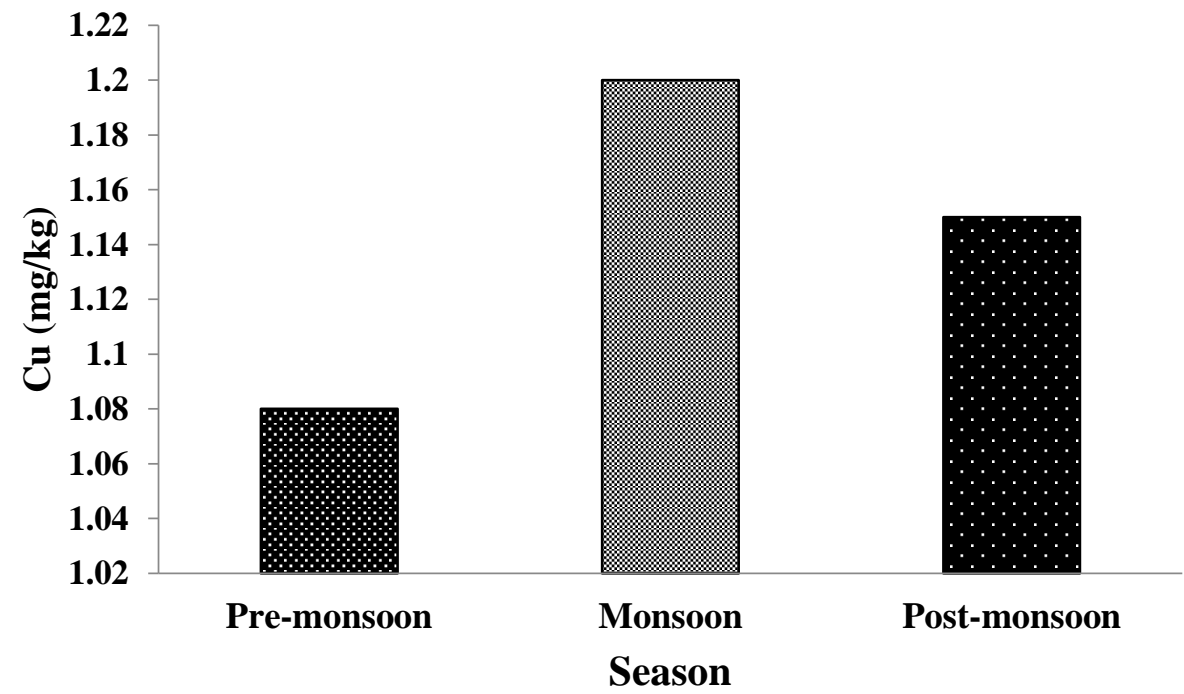

Figure 6: Seasonal variation of $\mathrm{Cu}$ concentration in Loittya (H. nehereus) from Pathorghata 


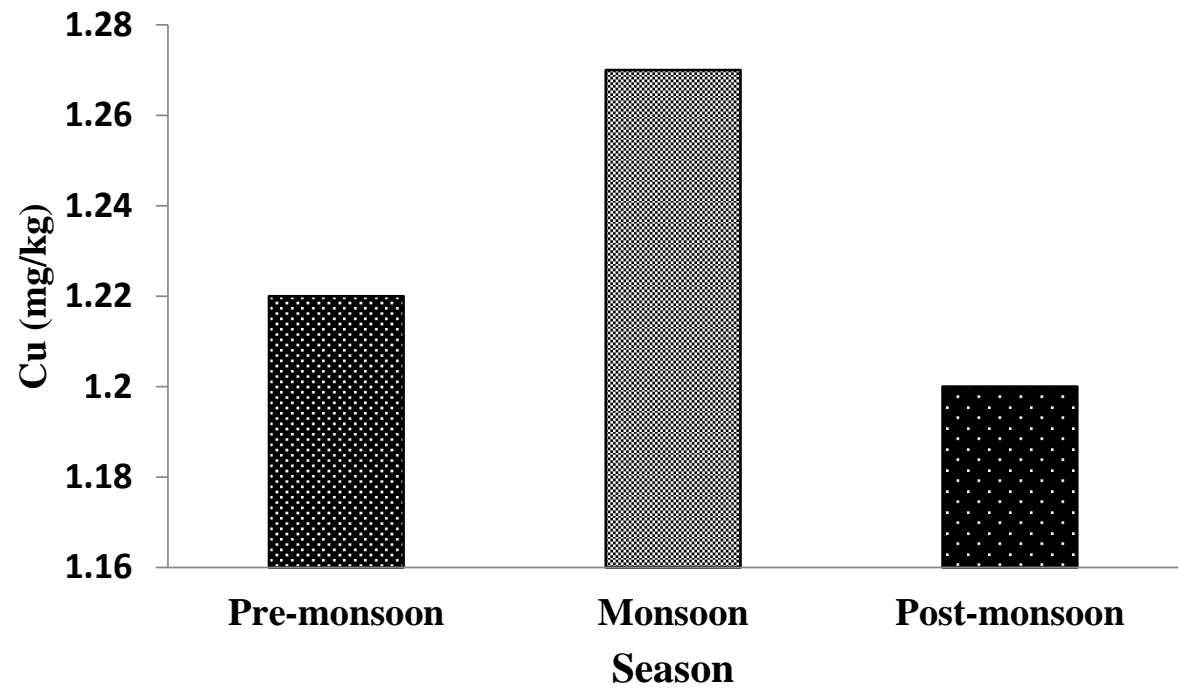

Figure 7: Seasonal variation of $\mathrm{Cu}$ concentration in Ilish (T. ilisha) from Pathorghata

Chromium (Cr): The presence of $\mathrm{Cr}$ in the diet is essential due to its active involvement in insulin function and lipid metabolism (Saha et al., 2016; Ahmed et al., 2015). In Poa fish, the mean concentration of $\mathrm{Cr}$ were $0.25,0.77$ and $0.52 \mathrm{mg} / \mathrm{kg}$ in pre-monsoon, monsoon and post-monsoon seasons, respectively (Table 4) with the highest and lowest content of 0.77 and $0.25 \mathrm{mg} / \mathrm{kg}$ at monsoon and pre-monsoon seasons, respectively. The $\mathrm{Cr}$ concentration was within the acceptable limit of FAO/WHO (1989) standard. Saha et al. (2016) reported that the marine fish A. cruciger accumulated the highest amount $(4.66 \mu \mathrm{g} / \mathrm{g})$ of $\mathrm{Cr}$ during summer, while $C$. reba accumulated the lowest amount $(1.27 \mu \mathrm{g} / \mathrm{g})$ during winter.

Table 4: Seasonal variations of Cr concentration $(\mathrm{mg} / \mathrm{kg})$ in fish of Pathorghata (Barguna)

\begin{tabular}{lcccc}
\hline \multirow{2}{*}{ Marine fish } & \multicolumn{3}{c}{ Seasons } & FAO/WHO \\
\cline { 2 - 4 } & Pre-monsoon & Monsoon & Post-monsoon & (1989) \\
\hline Poa (O. pama) & 0.25 & 0.77 & 0.52 & \\
Loittya (H. nehereus) & 0.48 & 0.40 & 0.56 & 1.00 \\
Ilish (T. ilisha) & 0.40 & 0.25 & 0.34 & \\
\hline
\end{tabular}

During the study, mean $\mathrm{Cr}$ concentrations in Loittya was $0.48,0.40$ and $0.56 \mathrm{mg} / \mathrm{kg}$ in premonsoon, monsoon and post-monsoon seasons, respectively (Table 4). The highest content (0.56 $\mathrm{mg} / \mathrm{kg})$ was found at post-monsoon and the lowest $(0.40 \mathrm{mg} / \mathrm{kg})$ was at monsoon season. In premonsoon, monsoon and post-monsoon seasons, the mean $\mathrm{Cr}$ concentrations were found $0.40,0.25$ and $0.34 \mathrm{mg} / \mathrm{kg}$, respectively; in Ilish fish whereas, the highest content was $0.40 \mathrm{mg} / \mathrm{kg}$ at premonsoon and lowest was $0.25 \mathrm{mg} / \mathrm{kg}$ at monsoon season (Table 4). The study found that $\mathrm{Cr}$ concentrations in fish species were within the acceptable limit set by FAO/WHO (1989). Ikem and Egiebor (2008) reported that the average concentration of $\mathrm{Cr}$ is $1.42 \mathrm{mg} / \mathrm{kg}$ in fish of Virginia and Alabama states of USA, which are much higher than present study.

$\mathrm{Pb}, \mathrm{Cd}$ and $\mathrm{Hg}$ : These heavy metals were not detected in the five marine fish species during the laboratory examination. The $\mathrm{Pb}$ was the metal which observed in below detectable level in all the 
given seven deep sea fish species, and Cd was found only in Neobyticus where in remaining all six deep sea fish species, this metal was in below detectable level (Rao and Sreedhar, 2017).

Table 5: Comparison of heavy metal concentrations in marine fish at different seasons

\begin{tabular}{cccccc}
\hline $\begin{array}{c}\text { Heavy } \\
\text { metals }\end{array}$ & $\begin{array}{c}\text { Rao and } \\
\text { Sreedhar (2017) }\end{array}$ & $\begin{array}{c}\text { Saha et al. } \\
(2016)\end{array}$ & $\begin{array}{c}\text { Kamal et al. } \\
(2013)\end{array}$ & $\begin{array}{c}\text { Present } \\
\text { study }\end{array}$ & $\begin{array}{c}\text { FAO/WHO } \\
\text { (1989) standard }\end{array}$ \\
\hline $\mathrm{Zn}$ & $17.35-28.31$ & $13.22-74.36$ & $3.71-20.54$ & $2.48-12.46$ & 40.00 \\
$\mathrm{Cu}$ & $15.54-24.38$ & $5.21-8.54$ & $0.25-0.91$ & $0.46-2.48$ & 30.00 \\
$\mathrm{Cr}$ & $\mathrm{NA}$ & $1.27-4.66$ & $\mathrm{NA}$ & $0.25-0.77$ & 1.00 \\
$\mathrm{Cd}$ & 0.03 & $0.47-0.02$ & 0.09 & $\mathrm{ND}$ & 0.50 \\
$\mathrm{~Pb}$ & $\mathrm{BDL}$ & $0.80-6.23$ & 0.55 & $\mathrm{ND}$ & 0.50 \\
\hline
\end{tabular}

Note: NA $=$ Not Analyzed, ND $=$ Not Detected, BDL $=$ Below Detection Limit (Palarea-Albaladejo and Martin-Fernandez, 2013).

A comparative study was also performed to depict the status of heavy metals bioaccumulation in fish from the Bay of Bengal coast in relation to others marine fish (Table 5). The study depicted that the Zn contamination were within standard level where Saha et al. (2016) showed higher level of $\mathrm{Zn}$ and $\mathrm{Pb}$ contamination that exceed the standard level set by FAO/WHO (1989) for marine fisheries. The other metal such as $\mathrm{Cu}, \mathrm{Cr}$ and $\mathrm{Cd}$ were within the standard level. From the overall analysis, it can be stated that the heavy metals contamination in fish of the Bay of Bengal is less than the other locations/ countries.

\section{Conclusions}

The result of the study concluded that only $\mathrm{Zn}$ was detected over the three seasons in all stations. The $\mathrm{Cu}$ was detected only in post-monsoon season in $\mathrm{St}-2$, whereas it was detected in all seasons at St-3. However, Cr was detected only at St-3 in all seasons. Other heavy metals $(\mathrm{Cd}, \mathrm{Pb}$ and $\mathrm{Hg})$ were not found in the laboratory investigation. Detected heavy metals in fish were within the acceptable limit as well as safe for human consumption. It could be due to the collection of fish from the deep sea where it was calm and far from the industrial activities. The study contributes significant addition to the existing knowledge of science regarding heavy metals contamination in marine fish in Bangladesh for safe consumption.

\section{Acknowledgements}

Sincere appreciation to the Ministry of Science and Technology (MoST) of the People's Republic of Bangladesh for the financial support (Grant Serial No. ES-342, 2017-18) to carry out the research and successfully.

\section{References}

Ahmed, M.K., Shaheen, N., Islam, M.S., Habibullah-al-Mamun, M., Islam, S. and Mohiduzzaman, M. (2015). Dietary intake of trace elements from highly consumed cultured fish (Labeo rohita, Pangasius pangasius and Oreochromis mossambicus) and human health risk implications in Bangladesh. Chemosphere, 128: 284-292. 
Amin, M.N., Begum, A. and Mondal, G.K. (2011). Trace element concentrations present in five species of freshwater fish of Bangladesh. Bangladesh Journal of Scientific and Industrial Research, 46(1): 27-32.

AOAC (Association of Official Analytical Chemists) (2012). AOAC international. Official methods of analysis, 19th edition, Association of Official Analytical Chemists, Washington DC, USA.

Asuquo, F.E., Ewa-Oboho, I., Asuquo, E.F. and Udo, P.J. (2004). Fish species used as biomarker for heavy metal and hydrocarbon contamination for Cross river, Nigeria. Environmentalist, 24: 29-37.

Bashir, F.A. and Alhemmali, E.M. (2015). Analysis of some heavy metal in marine fish in muscle, liver and gill tissue in two marine fish spices from Kapar coastal waters, Malaysia. In: the 2nd symposium on theories and applications of basic and biosciences, 5 September 2015, Malaysia, pp. 18-26.

BOBLME (The Bay of Bengal Large Marine Ecosystem) (2015). Report of the international seminar on pollution in water ways of Bangladesh, 16 January 2015, Dhaka, Bangladesh. BOBLME-2015-Ecology-24, 28 p.

Boran, M. and Altinok, N. (2010). A review of heavy metals in water, sediment and living organisms in the Black sea. Turkish Journal of Fisheries and Aquatic Sciences, 10: 565572.

Canli, M. and Atli, G. (2003). The relationships between heavy metal (Cd, Cr, Cu, Fe, Pb, Zn) levels and the size of six Mediterranean fish species. Environment Pollution, 121: 129-136.

Cid, B., Boia, C., Pombo, L. and Rebelo, E. (2001). Determination of trace metals in fish species of the Ria de Aveiro (Portugal) by electro thermal atomic absorption spectrometry. Food Chemistry, 75: 93-100.

El-Moselhy, K.M., Othman, A.I., El-Azem, H.A. and El-Metwally, M.E.A. (2014). Bioaccumulation of heavy metals in some tissues of fish in the Red Sea, Egypt. Egyptian Journal of Basic and Applied Sciences, 1(2): 97-105.

FAO/WHO (Food and Agricultural Organization/ World Health Organization) (1989). Evaluation of certain food additives and the contaminants mercury, lead and cadmium. WHO technical report, series no. 505.

Fernandes, C., Fontaínhas-Fernandes, A., Cabral, D. and Salgado, M.A. (2008). Heavy metals in water, sediment and tissues of Liza saliens from Esmoriz-Paramos lagoon, Portugal. Environment Monitoring and Assessment, 136: 267-275.

Geetha, S., Krishna, N.M., Rao, R., Rao, K.G. and Babu, R. (2016). Microbial assessment of commercially important crabs from Visakhapatnam fishing harbor, east coast of India. European Journal of Experimental Biology, 6(4): 57-61.

Gulmini, M., Ostacoli, G. and Zelano, V. (1994). Comparison between microwave and conventional heating procedures in tessier's extractions of calcium, copper, iron and manganese in lagoon sediment. Analyst, 119: 2075-2080.

Huseen, M.H. and Mohammed, A.J. (2019). Heavy metals causing toxicity in fish. IOP Conference Series: 1-10.

Ikem, A. and Egiebor, N.O. (2008). Assessment of trace elements in canned fish (mackerel, tuna, salmon, sardines and herrings) marketed in Georgia and Alabama (United States of America). Journal of Food Composition and Analysis, 18: 771-787.

Islam, M.S., Shil, S.C., Kabir, M.H. and Hoq, M.E. (2017). Investigation of heavy metal contamination in fish from Passur river near the Sundarbans mangroves of Bangladesh. Journal of Environmental Science and Natural Resources, 10(1): 21-24. 
Jafrin, N., Saif, A.N.M. and Hossain, M.I. (2016). Blue economy in Bangladesh: proposed model and policy recommendations. Journal of Economics and Sustainable Development, 7(21): 131-135.

Kamal, J.E., Shareef, K.M. and Nizam, M.E. (2013). Heavy metal concentrations in some commercially important fish and their contribution to heavy metals exposure in Palestinian people of Gaza strip (Palestine). Journal of the Association of Arab Universities for Basic and Applied Sciences, 13: 44-51.

Komarnicki, G.J.K. (2005). Lead and cadmium in indoor air and the urban environment. Environmental Pollution, 136: 47-61.

Krushevska, A., Barnes, M.R. and Amarasiriwaradena, C. (1993). Decomposition of biological samples for inductively coupled plasma atomic emission spectrometry using an open focused microwave digestion system. Analyst, 118: 1175-1181.

Kumar, G., Karthik, L. and Rao, K.V.B. (2010). In vitro anti-candida activity of Calotropis gigantea against clinical isolates of candida. Journal of Pharmacy Research, 3(3): 539-542.

Lal, B.V. and Fortune, K. (2000). The Pacific Islands: An Encyclopedia. University of Hawaii Press, p. 8.

Lorenzon, S, Francese, M., Smith, J. and Ferrero, E.A. (2001). Heavy metals affect the circulating haemocyte number in the shrimp Palaemon elegans. Fish and Shellfish Immunology, 11: 459-472.

Moula, G., Parvin, F. and Ferdaus, J. (2014). The prospects and challenges before Bangladesh in exploring and exploiting marine resources: an economic and legal study. Beijing Law Review, 5: 249-252.

Najjar, T.A, Momani, R.A., Khalaf, M., Wahsha, M., Sbaihat, M., Khalaf, N., Khadra, K.A. and Magames, H. (2016). Levels of heavy metals in fish (Cheilinus trilobatus) from the Gulf of Aqaba, Jordan. Natural Science, 8: 256-263.

Palarea-Albaladejo, J. and Martin-Fernandez, J.A. (2013). Values below detection limit in compositional chemical data. Analytica Chimica Acta, 764: 32-43.

Rahman, M.S., Saha, N. and Molla, A.H. (2014). Potential ecological risk assessment of heavy metal contamination in sediment and water body around Dhaka export processing zone, Bangladesh. Environment and Earth Science, 71(5): 2293-2308.

Rao, K.R. and Sreedhar, U. (2017). Proximate composition and heavy metal accumulation in some selected deep sea fish along the continental slope (200 to 1200M depth) of Indian EEZ (Exclusive Economic Zone). International Journal of Multidisciplinary Educational Research, 6(8): 77-92.

Rao, K.R., Viji, P., Sreeramulu, K. and Sreedhar, U. (2016). Proximate composition and heavy metal accumulation in deep-sea crustaceans from selected stations in the Indian exclusive economic zone (EEZ). Fishery Technology, 53(2): 155-161.

Raposo, J.C, Bartolome, E.L., Cortazar, E.E., Arana, E.J., Zabaljauregui, E.M., de Diego, E.M., Zuloaga, E.O., Madariaga, E.J.M. and Etxebarria, E.M. (2009). Trace metals in oysters, Crassotrea sps. from UNESCO protected natural reserve of Urdaibai: space-time observations and source identification. Bulletin of Environmental Contamination and Toxicology, 83: 223-229.

Saha, N., Mollah, M.Z.I., Alam, M.F. and Rahman, M.S. (2016). Seasonal investigation of heavy metals in marine fish captured from the Bay of Bengal and the implications for human health risk assessment. Food Control, 70: 110-118.

Shrivastava, A. and Gupta, V.B. (2011). Methods for the determination of limit of detection and limit of quantitation of the analytical methods. Chronicles of Young Scientists, 2(1): 21-25. 
Sivaperumal, P., Sankar, T. and Nair, P.V. (2007). Heavy metal concentrations in fish, shellfish and fish products from internal markets of India vis-a-vis international standards. Food Chemistry, 102(3): 612-620.

Sow, A.Y., Ismail, A. and Zulkifli, S.Z. (2013). An assessment of heavy metal bioaccumulation in Asian swamp eel, Monopterus albus, during plowing stages of a paddy cycle. Bulletin of Environmental Contamination and Toxicology, 91: 6-12.

Tang, W., Zhao, Y., Wang, C., Shan, B. and Cui, J. (2013). Heavy metal contamination of overlying waters and bed sediments of Haihe basin in China. Ecotoxicology and Environmental Safety, 98: 317-323.

Tao, Y., Yuan, Z., Xiaona, H. and Wei, M. (2012). Distribution and bioaccumulation of heavy metals in aquatic organisms of different trophic levels and potential health risk assessment from Taihu Lake, China. Ecotoxicology and Environmental Safety, 81: 55-64.

Tuzen, M. (2003). Toxic and essential trace elemental contents in fish species from the Black sea, Turkey. Food and Chemical Toxicology, 47: 1785-1790.

Xia, X.H., Chen, X., Liu, R.M. and Liu, H. (2011). Heavy metals in urban soils with various types of land use in Beijing, China. Journal of Hazard and Meteorology, 186: 2043-2050. 